\title{
Capital Inflows and Exchange Rate in Nigeria
}

\author{
Nwosa Philip Ifeakachukwu \\ Department of Economics, Accounting and Finance \\ College of Management Sciences, Bells University of Technology, Ota, Ogun State, Nigeria \\ nwosaphilip@yahoo.com
}

\author{
Amassoma Ditimi \\ Adeleke University, Ede, Osun State, Nigeria \\ Faculty of Business and Social Science, Economics Department \\ Email: amassoma.dit@gmail.com
}

\section{Doi:10.5901/mjss.2014.v5n7p263}

\begin{abstract}
This study examined the causal nexus between capital inflows (foreign direct investment and foreign portfolio investment) and exchange rate in Nigeria. It also examined the impact of these capital inflows on exchange rate in Nigeria for the period spanning 1986 to 2011. The study employed both granger causality and error correction modelling techniques. The causality estimates showed no causal link between capital inflows (foreign direct investment and foreign portfolio investment) and exchange rate within this period. The long run regression estimate revealed that foreign direct investment had negative effect on exchange rate while portfolio investment had positive impact on exchange rate. However, the magnitude of the impacts was very minute unlike the international oil price which had a strong negative effect on the exchange rate. The result of the short run result was similar to the causality result, indicating that neither foreign direct investment nor foreign portfolio investment had significant impact on exchange rate. The study concluded that the relationship between capital inflows and exchange rate in Nigeria is a long run phenomenon.
\end{abstract}

Keywords: foreign direct investment; foreign portfolio investment; causality; ECM; Nigeria.

\section{Introduction}

Foreign capital inflows have been perceived as an important source of augmenting the saving-investment gap in most resource deficient economies like Nigeria. However, massive capital inflows put pressure on the exchange rate of the domestic country's currency (Ghosh, 2010, De Paula et al., 2012), thereby reducing the trade competitiveness of the economy. Such decline trade competitiveness could escalate public internal and external debt; deteriorates fiscal deficit and even worsen the current account balance (De Paula, et al., 2012; Rashid \& Husain, 2010). Also, massive capital inflows create a strong challenge for economic managers in the conduct of macroeconomic policies. This is because attempts at curbing exchange rate appreciation monetary policy tightening, may even result in additional inflow of foreign capital into the domestic economy (given that higher interest differentials are signals for higher returns) and thereby putting further pressure on the exchange rate. Besides, large-scale sterilised foreign exchange market intervention by the monetary authority to curtail exchange appreciation from large capital inflows may even lose their effect or become increasingly costly as domestic interest rate continues to rise (Caruana, 2011).

In spite of the various macroeconomic problems associated with exchange rate appreciation which may result from massive capital inflows, there appeared to be less emphasis on foreign capital inflows-exchange rate relationship in developing countries in general and the Nigeria economy in particular. Most studies in this area have focused on emerging market economies (Combes et al., 2010; Elbadawi et al., 2008; Lartey, 2007; Chakraborty, 2003). This is rather worrisome because the Nigerian economy since the adoption of structural adjustment program in 1986 has witnessed increase inflows of foreign private capital which may portray a severe threat for the domestic economy through exchange rate appreciation. The few endogenous studies on capital inflows-exchange rate nexus (see Osinubi \& Amaghionyeodiwe, 2009; Ogunleye, 2008; Udoh \& Egwaikhide, 2008) only examined the effect of exchange rate volatility on foreign direct investment. These studies did not consider the direction of causation between these variables and particularly failed to examine the effect of foreign capital inflows on exchange rate. Also these studies only considered 
foreign direct investment without taking into account foreign portfolio investment which has been an important component of private capital inflows in Nigeria since 1986. Therefore, this study differs from previous studies by carrying out a comprehensive analysis of the nexus between exchange rate and foreign capital flows (particularly foreign direct investment and foreign portfolio investment).

In particular, this study is interested in understanding if "there are evidences that increased capital inflows are associated with exchange rate appreciation in Nigeria". The findings of the study would not only reveal the crucial role of foreign capital inflows in determining exchange rate movements in Nigeria, but would also shed light on the appropriate measures of dealing with exchange rate movement. Furthermore, as a guide for proactive and appropriate policy formulation, it is germane for policymakers devising policies for attracting foreign capital to know the direction of influence between foreign capital inflows and exchange rate.

In addition to the introductory section, the remaining parts of this article are as follows: section two focused on the review of related literature while section three focused on the research methodology. In section four, the analysis and interpretation of empirical results is discussed while the conclusion and policy recommendations is the main focus of section five.

\section{Literature Review}

Vast literature have examined issues concerning capital inflows on the one hand and exchange rate on the other hand. With respect to exchange rate, studies have explored the relationship between exchange rate and economic growth (see Shehu \& Youtang, 2012; Chen, 2012; Petreski, 2009; Eichengreen, 2007; Schnabl, 2007; Aurangzeb et al., 2005; Garofalo, 2005) while other studies have explored the relationship between exchange rate and trade flows (see Ibikunle \& Isaac, 2011; Hosseini pour \& Moghaddasi, 2010; Omisakin et al., 2010; Omojimite \& Akpokodje, 2010; Aliyu, 2008; 2009; Bahmani-Oskooee \& Kovyryalova, 2008; Bahmani-Oskooee \& Wang, 2008; Ozturk, 2006; Azaikpono, et al., 2005; BravoOrtega \& Di-Giovanni, 2005; Esquivel \& Felipe, 2002). Literature also dominates on capital inflows-economic growth (see Fasanya, 2012; Eshenake \& Oriavwote, 2012; Babalola et al., 2012; Umoh et al., 2012; Egwaikhide, 2012; Macaulay, 2011; Shen et al., 2010; Waldkirch, 2008; Tang et al., 2008; Ozturk \& Kalyoniu, 2007; Prasad et al., 2007; Le, 2007; Akinlo, 2004). Yet others analysed the determinants of capital flows in a country (see Obida and Abu, 2012; Okpara et al., 2012; Okafor, 2012; Anyanwu, 2011; Nasrin et al., 2010; Walsh \& Yu, 2010; Ewe-Ghee, 2001).

Particularly, the relationship between capital inflows and exchange rate has been studied more extensively in industrialised countries and emerging markets economies while little attention has been paid to it in Nigerian. Ellahi (2011) observed that exchange rate volatility negatively influenced foreign direct inflow in short run while in the long run exchange rate volatility positively influenced foreign direct investment in Pakistan for the period 1980 to 2010. Combes et al. (2010) revealed that both public and private inflows resulted in the appreciation of real effective exchange rate. Among private inflows, portfolio investment has the biggest impact on appreciation, almost seven times that of foreign direct investment or bank loans while private inflows have the smallest effect. Further, the study used a de facto measure of exchange rate flexibility and observed that a more flexible exchange rate helps to dampen appreciation of the real effective exchange rate caused by capital inflows. Dhakal et al. (2010) and Del and Chiara (2009) observed a significant positive relationship between exchange rate volatility and foreign direct investment while Chege (2009) and Barrell et al. (2004) observed a negative relationship between exchange rate volatility and inward foreign direct investment.

Osinubi and Amaghionyeodiwe (2009) examined the effect of exchange rate volatility on foreign direct investment (FDI) in Nigeria for the period 1970 to 2004. Utilizing the Ordinary Least Square (OLS) and the error correction model (ECM) estimation techniques the study revealed a significant positive relationship between real inward FDI and exchange rate. The study also suggested that exchange rate volatility need not be a source of worry for foreign investors in Nigeria. Ogunleye (2008) examined the relationship between exchange rate volatility and foreign direct investment in Nigeria and South Africa. The study observed that exchange rate volatility negatively influenced FDI inflows while FDI inflows aggravated exchange rate volatility in both countries. Abdul (2009) examined the effects of capital inflows on nominal and real effective exchange rate volatilities in Pakistan for the period 1991:1 to 2007:12. Using granger causality test, the study observed a significant causal relationship between foreign capital inflows and exchange rate volatility. The study recommended the need to manage capital inflows in such a way that they should not fuel the exchange rate volatility.

Udoh and Egwaikhide (2008) examined the effect of exchange rate volatility and inflation uncertainty on foreign direct investment in Nigeria for the period 1970 to 2005. Exchange rate volatility and inflation uncertainty were estimated using the GARCH model and the result showed that exchange rate volatility and inflation uncertainty exerted significant negative influence on foreign direct investment. The study further revealed that infrastructural development, appropriate size of the government sector and international competitiveness are crucial determinants of FDI inflow to the country. 
Due and Sen (2006) examined the nexus among real exchange rate, capital flows (level and volatility), fiscal and monetary policy indicators and the current account surplus in India. Using a quarterly data spanning 1993:2 to 2004:1, the study observed the existence of co-integration among the variables while each of the variables was observed to granger cause the real exchange rate. Further evidence from the Generalized Variance Decomposition (GVD) analysis revealed that net capital flows (level and volatility) are the most significant determinant of real exchange rate, and this was followed by government expenditure, current account surplus and money supply respectively. Earlier study by Chakraborty (2003) in India using quarterly data for the period 1993:2 to 2001:1 revealed that real effective exchange rate is influenced by foreign capital inflows. Froot and Stein (1989) analysing the relationship between exchange rates and FDI observed that a depreciated currency can boost foreign direct investment while studies by Elbadawi et al. (2008), Lartey (2007), Prati et al. (2003), Bulir and Lane (2002) and Kasekende and Atingi-Ego (1999) reported that official flows are associated with exchange rate appreciation.

As argued in the introductory section, the review above clearly showed that previous endogenous studies only focused on foreign direct investment without taking into cognizance portfolio investment which is also an important component of capital inflows in Nigeria since 1986. Previous studies also did not consider the direct link between the size of foreign capital inflows (foreign direct investment and foreign portfolio investment) and exchange rate in Nigeria. This is the empirical gap this study intends to fill in the literature.

\section{Research Methodology}

Specifically, this study addresses two key issues: the causal nexus between capital inflows and exchange rate; and the impact of capital inflows on exchange rate. To this end, two models are specified:

\subsection{Model on Causality}

To examine the causal nexus between capital inflows and exchange rate, a bi-variate granger causality technique is employed. The appropriate specification of the model (that is, whether in VAR or VECM) depends on the properties of the unit roots of the variables and also on the existence of co-integration between the variables. If the variables are not cointegrated, then a VAR model specified of equations (1) and (2) is utilized.

$$
\begin{aligned}
& Y_{t}=\sum_{i=1}^{n} \alpha_{11} Y_{t-i}+\sum_{i=1}^{n} \alpha_{12} X_{t-i}+u_{1 t} \\
& X_{t}=\sum_{i=1}^{n} \alpha_{21} Y_{t-i}+\sum_{i=1}^{n} \alpha_{22} X_{t-i}+u_{2 t}
\end{aligned}
$$

Where $Y_{t}$ refers to capital inflows and $X_{t}$ refers to exchange rates. On the other hand, if the variables are cointegrated then, the VAR model must include an error correction term. Engel-Granger (1987) cautioned that the Granger causality test, which is conducted in the first differences of variables through a vector auto-regression (VAR) is misleading in the presence of co-integration. Therefore, an inclusion of an additional variable to the VAR system, such as the error correction term would help capture the long run relationship among the variables (Nwosa and Ajibola, 2013; Nwosa, 2012). To this end, an augmented form of causality test involving the error correction term is formulated in a bi-variate pth order vector error-correction model (VECM) as follows (Ferda, 2007).

$$
\left[\begin{array}{l}
\Delta Y_{t} \\
\Delta X_{t}
\end{array}\right]=\left[\begin{array}{l}
\varphi_{10} \\
\varphi_{20}
\end{array}\right]+\sum_{i=1}^{p}\left[\begin{array}{ll}
\alpha_{11} & \alpha_{12} \\
\alpha_{21} & \alpha_{22}
\end{array}\right]\left[\begin{array}{c}
\Delta Y_{t-i} \\
\Delta X_{t-i}
\end{array}\right]+\left[\begin{array}{c}
\lambda_{1} \\
\lambda_{2}
\end{array}\right]\left[E C T_{h, t-1}\right]+\left[\begin{array}{l}
u_{1 t} \\
u_{2 t}
\end{array}\right]
$$

where $E C T_{h, t-1}$ is the error correction term, the residual from the $h$ th co-integration equation lagged one period.

\subsection{Model on the Impact of Capital Inflows on Exchange Rate}

To estimate the impact of capital inflows (foreign direct investment and foreign portfolio investment) on exchange rate, a simple model is specified below:

$$
E X T_{t}=\alpha_{0}+\alpha_{1} F D I_{t}+\alpha_{2} F P I_{t}+\alpha_{3} O P N X_{t}+\alpha_{4} O I_{t}+\varepsilon_{t}
$$

In addition to estimating the long run relationship above, the study also attempts to examine the short run relationship between the variables by specifying the short run error correction model below: 


$$
\Delta E X T_{t}=\alpha_{0}+\sum_{i=1}^{n} \alpha_{1} \Delta E X T_{t-i}+\sum_{i=1}^{n} \alpha_{2} \Delta F D I_{t-i}+\sum_{i=1}^{n} \alpha_{3} \Delta F P I_{t-i}+\sum_{i=1}^{n} \alpha_{4} \Delta O P N X_{t-i}+\sum_{i=1}^{n} \Delta \alpha_{5} O I L_{t-i}+\psi E C T_{t-1}+\mu_{t}
$$

The $E C T_{\mathrm{t}-1}$ is the error correction term of the short run equation.

\subsection{Data Description, Measurement and Sources}

EXT refers to real exchange rate measured by the annual Naira/Dollars ( $\$$ / official exchange rate; FDI is foreign direct investment measured by the annual FDI inflow into the country; FPI is portfolio investment measured by the annual portfolio investment inflow into the country; OPNX is trade openness measured as the ratio of non-oil import plus non-oil export to real gross domestic product (RGDP); OIL is the oil price measured by the international oil price. Exchange rate, foreign direct investment, portfolio investment, non-oil export, non-oil import, real gross domestic product were sourced from the Central Bank of Nigeria Statistical Bulletin while international oil price is sourced from the Federal Research Bank of St. Louis Statistical bulletin.

\section{Empirical Result}

\subsection{Unit Root and Co-integration Tests}

The stationarity test of the variables was conducted using the Philip-Perron test. As observed on table 1, it is revealed that the variables were non-stationary in their level form, thus leading to the testing of the variables at first differences, which revealed that all the variables were stationary at first difference, that is, integrated of order one I(1).

Table 1. Unit Root Test

Note: ${ }^{*}=1 \%$ and ${ }^{* *}=5 \%$ significance level.

\begin{tabular}{|c|c|c|c|}
\hline \multicolumn{4}{|c|}{ Phillip-Perron (PP) Test } \\
\hline Variables & Level & 1 $^{\text {st }}$ Difference & Remarks \\
\hline ext & -0.3661 & $-4.7350^{\star}$ & $\mathrm{I}(1)$ \\
\hline fdi & -1.3651 & $-4.0540^{\star}$ & $\mathrm{I}(1)$ \\
\hline fpi & -2.1631 & $-8.2694^{\star}$ & $\mathrm{I}(1)$ \\
\hline loip & -0.5633 & $-8.7958^{\star}$ & $\mathrm{I}(1)$ \\
\hline opnx & 3.7569 & $-5.6967^{\star}$ & $\mathrm{I}(1)$ \\
\hline Igdp & 1.0971 & $-3.3375^{\star}$ & $\mathrm{I}(1)$ \\
\hline
\end{tabular}

As a follow-up to the stationarity test, this study examined the existence of co-integration among the variables. However, based on the objectives of this study the co-integration test would be carried in two different forms. Based on causality objective, the co-integration between the pairs of variables (ext \& fdi; ext \& fpi), are carried out via the Engel-Granger cointegration test. The Engel-granger technique is observed to be most suitable for testing co-integration between two variables as against the Johansen co-integration test which is adopted when the model is a multi-variate, given the possibility of having more than one co-integrating vector. Since the causality objective only considers two-variable scenarios, then the problem of multi co-integration does not exist. The co-integration result based on Engel-Granger is presented in table 2 and from the table, the Engel-Granger tua-statistic and z-statistic estimates clearly showed that all pairs of variables were not co-integrated. This is because the probability values of these statistics tests were insignificant.

Table 2. Summary of the Co-integration Estimate on Causality

\begin{tabular}{|c|c|c|c|}
\hline & \multicolumn{3}{|c|}{ Engle-Granger Co-integration Test } \\
\hline \multirow{2}{*}{ Pairs of Variables } & $\begin{array}{c}\text { Dependents } \\
\text { Variables }\end{array}$ & $\begin{array}{c}\text { Tau-statistic } \\
\text { (Prob-value) }\end{array}$ & $\begin{array}{c}\text { Z-Statistic } \\
\text { (Prob-value) }\end{array}$ \\
\hline \multirow{2}{*}{ ext \& fdi } & ext & $-0.6995(0.9456)$ & $-1.0436(0.9681)$ \\
\cline { 2 - 4 } & fdi & $-1.2239(0.8533)$ & $-3.4402(0.8422)$ \\
\hline \multirow{2}{*}{ ext \& fpi } & ext & $-1.8006(0.6344)$ & $-5.6928(0.6411)$ \\
\cline { 2 - 4 } & fpi & $-1.8554(0.6093)$ & $87.5373(0.9999)$ \\
\hline
\end{tabular}

Source: Authors' computation 


\subsection{Causality Estimate}

Based on the co-integration estimates, the causal nexus between exchange rate and foreign direct investment; and between exchange rate and foreign portfolio were analysed using equations (1) and (2). The results are presented below.

Table 3. Pairwise Causality Estimates

\begin{tabular}{|l|c|}
\hline Null Hypothesis $\left(H_{0}\right)$ & F-Statistic (Probability) \\
\hline fdi does not granger cause ext & $0.0251(0.9752)$ \\
ext does not granger cause fdi & $1.8584(0.1832)$ \\
\hline fpi does not granger cause ext & $0.4296(0.6569)$ \\
ext does not granger cause fpi & $2.9207(0.0783)$ \\
\hline
\end{tabular}

Using the F-statistic and the probability value, table 3 revealed no evidence of causality between capital inflows (foreign direct investment (fdi) and foreign portfolio investment (fpi)) and exchange rate (ext), indicating that these variables do not influence each other in the short run at five per significant level.

\subsection{Regression Estimate}

\subsubsection{Co-integration and Long-run Regression Estimate}

With respect to equations (4) and (5) specified above, the Johansen co-integration test was applied to examine the existence of co-integration among the variables. From table 5, it was observed that the null hypothesis of no cointegration, for $r=0$ was rejected by the trace statistic because the statistic value was greater than the critical value, but was not rejected by the maximum-eigen statistic because the statistic value was less than the critical value. However, the null hypothesis of no co-integration at $r \leq 1$ could not be rejected by the trace statistics because the statistic value was less than the critical value. Based on the trace statistics there is one co-integrating equation while the maximum eigen-value statistics indicated no co-integration among the variables. In the light of the conflicting result, this study laid credence on the trace statistic test for a possible existence of a long run relationship among exchange rate, foreign direct investment, foreign portfolio investment, international crude oil price and trade openness.

Table 5. Summary of the Co-integration Estimate

\begin{tabular}{|c|c|c|c|c|c|c|c|}
\hline \multicolumn{3}{|c|}{ Trace Test } & \multicolumn{4}{c|}{ Maximum Eigen value Test } \\
\hline Null & alternative & Statistics & $95 \%$ critical values & Null & alternative & Statistics & $95 \%$ critical values \\
\hline$r=0$ & $r \geq 1$ & 73.303 & 69.819 & $r=0$ & $r=1$ & 30.993 & 33.877 \\
\hline$r \leq 1$ & $r \geq 2$ & 42.311 & 47.856 & $r \leq 1$ & $r=2$ & 19.414 & 27.584 \\
\hline$r \leq 2$ & $r \geq 3$ & 22.897 & 29.797 & $r \leq 2$ & $r=3$ & 11.708 & 21.132 \\
\hline$r \leq 3$ & $r \geq 4$ & 11.188 & 15.495 & $r \leq 3$ & $r=4$ & 7.515 & 14.265 \\
\hline
\end{tabular}

The long-run normalized co-integrating equation is presented as follows.

$\mathrm{LEXT}_{\mathrm{t}}=-1.92 \mathrm{E}-05 \mathrm{FDI}_{\mathrm{t}}{ }^{\star}+9.04 \mathrm{E}-06 \mathrm{FPII}_{\mathrm{t}}{ }^{\star *}-2.3308 \mathrm{LOIP}_{\mathrm{t}}{ }^{*}+0.30400 \mathrm{PNX} \mathrm{t}_{\mathrm{t}}$
SE: $\quad(2.9 \mathrm{E}-06)$
$(3.7 \mathrm{E}-06) \quad(0.8354)$
$(0.2053)$

Note: $*=1 \%$ and ${ }^{* *}=5 \%$ significance level.

The long run co-integrating equation showed that foreign direct investment, foreign private investment and international crude oil price are significant determinants exchange rate in Nigeria. It was observed from the result that an increase in the inflow of foreign direct investment would result in a significant appreciation of the domestic currency but the magnitude of such effect is very microscopic. A positive change in foreign portfolio investment is expected to result in a depreciation of domestic currency but the magnitude of this effect is also very microscopic. An increase in oil price is expected to result in a significant appreciation of the domestic currency. In contrast to the above, trade openness had insignificant influence on exchange rate in Nigeria. With respect to variable of interest, foreign direct investment and foreign portfolio investment had significant influence on exchange rate but the magnitude of such effects are vary infinitesimal compared to the large and significant effect of international oil price in the long run.

Before, analysing the short run regression estimate (that is equation (5)), the stationarity property of the residual 
from the long run estimates was examined and the result is presented in table 6 below. A key criterion for the estimation of the short run estimate (or error correction model) is that the residual from the long run estimate must be stationary at levels and at five percent. Thus, using the Phillip-Perron test, it is revealed that the residual from the model was stationary at levels and at five percent significant.

Table 6. Residual Stationarity Test

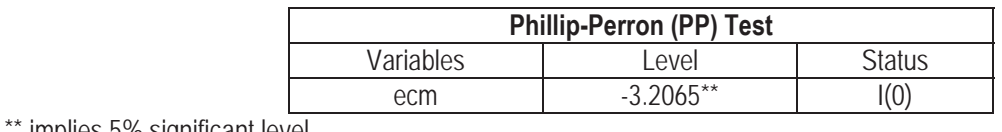

** implies 5\% significant level.

\subsubsection{Short run Estimate}

Following the residual stationarity test, we over parameterized the first differenced form of the variables in equation (5) and used Schwarz Information Criteria to guide parsimonious reduction of the model. This helps to identify the main dynamic pattern in the model and to ensure that the dynamics of the model have not been constrained by inappropriate lag length specification. Thus, the lag length on all variables in each model was set at two to ensure sufficient degrees of freedom.

From the short run parsimonious estimate reported on table 7, it was observed that the coefficient of the error-term was both statistically significant at five per cent and negative. The coefficient estimate of the error correction term of -0.37 implied that the model corrects its short run disequilibrium by about 37 percent speed of adjustment in order to return to the long run equilibrium. In addition, and with respect to the explanatory variables, it was observed that at one per cent significant level, the immediate past value of international crude oil price $(O I P(-1))$ strongly influenced current exchange rate. Also, at five per cent significant level, the immediate past value of exchange rate (LEXT(-1)) and the second lagged value of trade openness (OPNX(-2)) had significant influence on current exchange rate. With respect to the variables of interest (foreign direct investment and foreign portfolio investment), these variables were insignificant neither at one per cent nor at five per cent, indicating that these variables were not significant factors influencing current exchange rates in the short run in Nigeria.

Table 7. Parsimonious Short Run Regression Estimate

\begin{tabular}{|c|c|c|c|c|}
\hline Variables & Coefficient & Std. Error & t-Statistics & Probability \\
\hline C & -0.0117 & 0.0884 & -0.1326 & 0.8965 \\
\hline ECM(-1) & -0.3652 & 0.1449 & -2.5208 & 0.0256 \\
\hline$\Delta$ LEXT(-1) & 0.6135 & 0.2393 & 2.5638 & 0.0236 \\
\hline$\Delta \mathrm{LEXT}(-2)$ & 0.3116 & 0.1885 & 1.6528 & 0.1223 \\
\hline$\Delta \mathrm{FDI}$ & $1.9 \mathrm{E}-06$ & $9.1 \mathrm{E}-07$ & 2.0787 & 0.0580 \\
\hline$\Delta \mathrm{FDI}(-1)$ & $-2.2 \mathrm{E}-06$ & $1.0 \mathrm{E}-06$ & -2.1567 & 0.0503 \\
\hline$\Delta \mathrm{FPI}$ & $8.0 \mathrm{E}-07$ & $5.5 \mathrm{E}-07$ & -1.4637 & 0.1670 \\
\hline$\Delta \mathrm{LOIP}$ & 0.3509 & 0.1735 & 2.0230 & 0.0641 \\
\hline$\Delta \mathrm{LOIP}(-1)$ & -0.6492 & 0.2101 & -3.0905 & 0.0086 \\
\hline$\triangle O P N X(-2)$ & 0.2582 & 0.1158 & 2.2290 & 0.0441 \\
\hline R-Squared & 0.6314 & \multirow{3}{*}{\multicolumn{2}{|c|}{$\begin{array}{l}\text { S.D dependent Var: } \\
\text { F-Statistic } \\
\text { Prob. (F-Statistic) }\end{array}$}} & 0.3225 \\
\hline S.E of Regression & 0.2547 & & & 2.4746 \\
\hline D.W Stat & 2.03 & & & 0.0672 \\
\hline
\end{tabular}

\subsubsection{Diagnostic and Stability Tests}

The appropriateness of the short run (parsimonious) model was further verified by carrying out various diagnostic tests (the Serial Correlation LM test, the ARCH test, and the histogram and normality test) and stability tests (Cumulative Sum (CUSUM) and Cumulative Sum of squares (CUSUMSQ)) on the residual of the short run model. From the result of the tests presented below it was observed that, the Jarque-Bera statistic from the histogram and normality test was insignificant, implying that the residual from the error correction model is normally distributed. Also, the Serial Correlation and ARCH LM tests confirmed that there is no serial correlation in the residuals of the ECM regression estimate because 
the F-statistics of the model was insignificant. This showed that there are no lagged forecast variances in the conditional variance equation. In other words, the errors are conditionally normally distributed, and can be used for inference (Nwosa, et al., 2013; Nwachukwu \& Odigie, 2009). Further, the cumulative sum (CUSUM) and cumulative sum of squares (CUSUMSQ) tests presented on Figure 1 below revealed that the residuals of the error-correction model fell within the critical bounds of five percent significant level; implying that the estimated parameters are stable over the period 19862011. Overall, the model could be considered to be reasonably specified based on the results of the above tests.

Table 5a. Diagnostic Tests

\begin{tabular}{|lcc|}
\hline Tests & F-statistic & P-value \\
\hline Breusch-Godfrey Serial Correlation LM Test & 1.4584 & 0.2743 \\
Heteroskedasticity Test: ARCH & 0.2240 & 0.6411 \\
\hline
\end{tabular}

Table 5b. Histogram-Normality Test

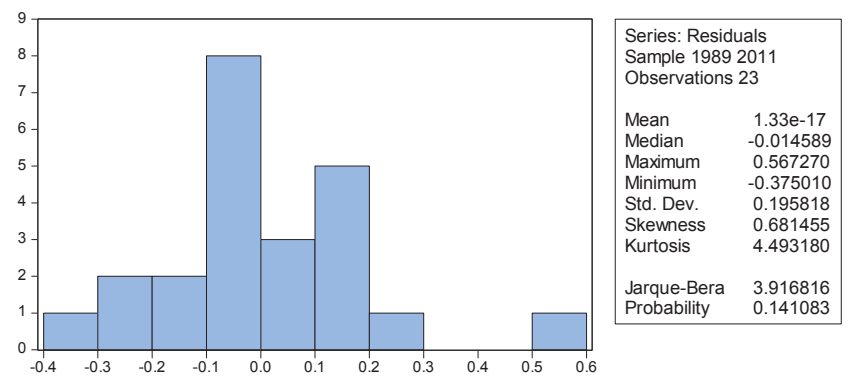

Figure 1. Stability Tests
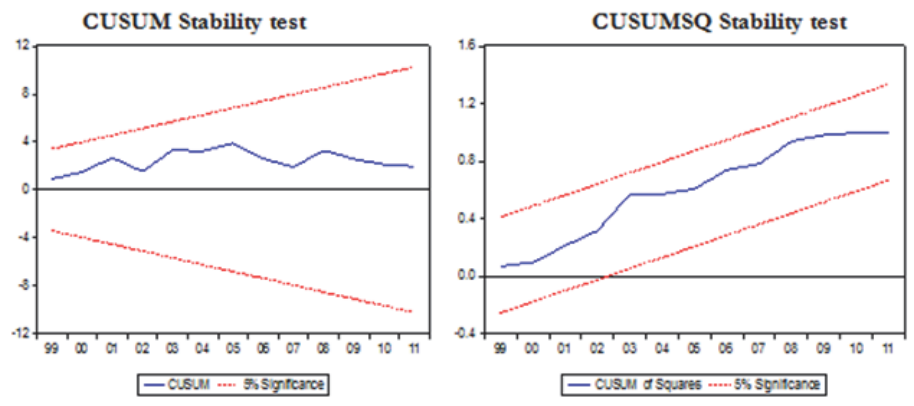

\section{Conclusion and Policy Recommendation}

This study focused on the relationship between capital inflows (foreign direct investment and foreign portfolio investment) and exchange rate in Nigeria for the period 1986 to 2011. Specifically, the study examined the causal nexus between capital inflows and exchange rate and also examined the relative effect of capital inflows on exchange rate in Nigeria. The causality estimates only revealed no causal link between capital inflows (foreign direct investment and foreign portfolio investment) and exchange rate. Based on the regression estimate, the long run regression showed that increase in foreign direct investment had an appreciating impact on exchange rate while an increase in portfolio investment had a depreciating impact on exchange rate. The result of the short run regression estimate was similar to the causality result, indicating that neither foreign direct investment nor foreign portfolio investment had significant impact on exchange rate.

The implication of the above result is that the relationship between capital inflows and exchange rate in Nigeria for the period 1986 to 2011 is a long run phenomenon and the magnitudes of the impact of capital inflows (foreign direct investment and foreign portfolio investment) are very minute unlike the international oil price which had a strong 
depreciating impact on current exchange rate. Base on these findings, this study recommends that appropriate policies should be formulated to encourage the inflow of foreign capital but with prudent moderations.

\section{Reference}

Abdul, R.A. (2009). Capital inflows and exchange rate volatility in Pakistan', International Conference on Applied Economics - ICOAE 2009, 571-578.

Aliyu S.U. (2008). Exchange rate volatility and export trade in Nigeria: an empirical investigation, Munich Personal RePEc Archive MPRA Paper No. 13490.

Aliyu S.U. (2009). Impact of oil price shock and exchange rate volatility on economic growth in Nigeria: an empirical investigation, Research Journal of International Studies, 11(8), 4-15.

Akinlo A. (2004). FDI and economic growth in Nigeria. An empirical investigation, Journal of Policy Modeling, 26(5), 627-639.

Anyanwu, J.C. (2011). Determinants of foreign direct investment inflows to Africa, 1980-2007, Working Paper Series No. 136. African Development Bank, Tunis, Tunisia.

Aurangzeb, A., Stengos, T., \& Muhammad, A. U. (2005). Short-run and long-run effects of exchange rate volatility on the volume of exports: a case study for Pakistan', International Journal of Business and Economics, 4(3), 209-222.

Aziakpono, M., Tsheole, T., \& Takaendasa, P. (2005). Real exchange rate and its effect on trade flows: new evidence from South Africa. Retrieved on June 20, 2013 from

http://www.essa.org.za/download/2005Conference/Takaendesa.pdf.

Babalola, S. J., Dogon-Daji, S. D-H., \& Saka, J. O. (2012). Exports, foreign direct investment and economic growth: an empirical application for Nigeria, International Journal of Economics and Finance, 4(4), 95-105.

Barrell, R., Gottschalk S. D., \& Hall, S. G. (2004). Foreign direct investment and exchange rate uncertainty in imperfectly competitive industries, Tanaka Business School Discussion Paper, TBS/DP04/7.

Bahmani-Oskoee, M., \& Kovyryalova, M. (2008). Impact of exchange rate uncertainty on trade flows; evidence from commodity trade between the US and the United Kingdom', The World Economy, 31(8), 1097-1128.

Bahmani-Oskoee, M., \& Wang, Y. (2008). Impact of exchange rate uncertainty on commodity trade between US and Australia', Australian Economic papers, 47(3), 235-238.

Bravo-Ortega, C., \& Di-Giovanni, J. (2005). Trade costs and real exchange rate volatility: the role of Ricardian comparative advantage', IMF Working Paper, WP/05/5.

Bulir, A., \& Lane, T. (2002). Aid and fiscal management'. IMF Working Paper, 02/112. (Washington: International Monetary Fund).

Caruana, J. (2011). Capital flows to the emerging market economies: a perspective on policy challenges, Forty-sixth SEACEN Governors' Conference, Colombo, Sri Lanka, 24-26 February, 2011.

Chakraborty, I. (2003). Liberalization of capital inflows and real exchange rate in India: A VAR analysis, IMF Working paper, No. 108.

Chege, E. (2009). Exchange rate volatility effects on inward foreign direct investments in emerging markets', Maastricht University Masters of Science in International Business. Retrieved on February 15, 2013 from

http://www.scribd.com/doc/87963643/EXCHANGE-RATE-VOLATILITY.

Chen, J. (2012). Real exchange rate and economic growth: evidence from Chinese provincial data (1992 - 2008), Paris School of Economics Working Paper, No. 5.

Combes, J-L., Kindab, T., \& Planec, P (2010). Capital flows and their impact on the real effective exchange rate, Document de travail de la serie, Etudes et Documents, E 2010.32.

De-Paula, L. F., Ferrari-Filho, F., \& Gomes, A. M. (2012). Capital flows, international imbalances and economic policies in Latin America, Retrieved on January 13, 2013 from http://www.ufrgs.br/PPGE/pcientifica/2012_12.pdf

Del, B., \& Chiara, F. M. (2009). Foreign direct investment, exchange rate volatility and political risk. Intervento presentato al 11. convegno ETSG annual conference tenutosi a Roma nel 2009

Dhakal, D., Nag, R., Pradhan, G., \& Upadhyaya, K. P. (2010). Exchange rate volatility and foreign direct investment: evidence from East Asian countries, International Business and Economics Research Journal, 9(7), 121-128

Due, P., \& Sen P. (2006). Capital flow volatility and exchange rates: the case of India, Working Paper No. 144, Central for Development Economics, Department of Economics, Delhi School of Economics.

Egwaikhide, C. I. (2012). The impact of foreign direct investment on Nigeria's economic growth; 1980-2009: evidence from the Johansen's co-integration approach, International Journal of Business and Social Science, 3(6), 122-134.

Eichengreen, B. (2007). The real exchange rate and economic growth, background paper for the World Bank Growth Commission, presented to the Commission meeting in New York City, 9 April 2007. Retrieved on May 20, 2013 from Available at http://emlab.berkeley.edu/ eichengr/real_exchange_rate.pdf]

Elbadawi, I. A., Kaltani, L., \& Schmidt-Hebbel, K. (2008). Foreign aid, the real exchange rate, and economic growth in the aftermath of civil wars, World Bank Economic Review, 22(1), 113-140.

Ellahi, N. (2011). Exchange rate volatility and foreign direct investment (FDI) behavior in Pakistan: a time series analysis with autoregressive distributed lag (ARDL) application, African Journal of Business Management, 5(29), 11656-11661.

Engle, R. F., \& Granger, C. W. J. (1987). Co-integration and error correction: representation, estimation and testing, Econometrica, 55(2), 251-276.

Eshenake, S. J., \& Oriavwote, V. E. (2012). Foreign direct investment in Nigeria: the roles of real effective exchange rate, market size, 
openness and inflation, European Journal of Economics, Finance and Administrative Sciences, 53(September), 106-113.

Esquivel, G., \& Felipe L. (2002). The impact of G-3 exchange rate volatility on developing countries, UNCTAD G-24 Discussion Paper Series, No. 16, Geneva.

Ewe-Ghee, L. (2001). Determinants of and the relation between, foreign direct investment and growth: a summary of the recent literature, IMF Working paper, WP/01/175.

Fasanya, I. O. (2012). Capital flows-growth nexus in Nigeria: has foreign direct investment played a role in accelerating economic growth? Journal of Sustainable Development in Africa, 14(8), 34-52.

Ferda, H. (2007). The financial development and economic growth nexus for turkey, Economic and Econometrics Research Institute (EERI) Research Paper Series, No. 6, Brussels, Belgium.

Froot, K. A., \& Stein, J. C. (1989). Exchange rates and foreign direct investment: an imperfect capital markets approach, NBER Working Paper, No. 2914. Cambridge, MA.

Garofalo, P. (2005). Exchange rate regimes and economic performance: the Italian experience. Banca D'Italia Quaderni dell'Uffficio Ricerche Storiche, No.10, (September). Retrieved on February 25, 2013 from

http://www.bancaditalia.it/pubblicazioni/pubsto/quaristo/qrs10/Q10_Garofalo.pdf

Ghosh, S. R. (2010). Dealing with the challenges of capital inflows in the context of macrofinancial link, in World Bank - Poverty Reduction and Economic Management Network, No. 19, June, Washington: World Bank.

Hosseini pour, M. H., \& Moghaddasi, R. (2010). Exchange rate volatility and Iranian export, World Applied Sciences Journal, 9(5), 499508.

Ibikunle, J. A., \& Isaac, A. (2011). An empirical investigation of the link between exchange rate volatility and trade in Nigeria, Journal of Emerging Trends in Economics and Management Sciences, 2(3), 175-183.

Kasekende, L. A., \& Atingi-Ego, M. (1999). Uganda's experience with aid, Journal of African Economies, 8(4), 617-649.

Lartey, E. (2007). Capital inflows and the real exchange rate: an empirical study of sub- Saharan Africa, Journal of International Trade and Economic Development, 16(3), 337-57.

Le, T. T. (2007). Does foreign direct investment have an impact on the growth in labor productivity of Vietnamese domestic firms?', RIETI Discussion Paper Series, 07-E-021.

Macaulay, E. D. (2011) 'Foreign direct investment and the performance of the Nigerian economy, Journal of Educational and Social Research, Vol. 1, No. 5, pp. 31-34.

Nasrin, S., Baskaran, A., \& Muchie M. (2010). Major determinants and hindrances of FDI inflow in Bangladesh: perceptions and experiences of foreign investors and policymakers, GLOBELICS-8th International Conference. Making Innovation Work for Society: Linking, Leveraging and Learning, University of Malaya, Kuala Lumpur, Malaysia, 1-3, November. 2010.

Nwachukwu, T. E., \& Odigie P. (2009). What drives private saving in Nigeria, A Paper Presented at the Centre for the Study of African Economies (CSAE) Conference, University of Oxford, March 2009.

Nwosa, P. I., Adediyi, O. O., \& Adedeji, A. O. (2013). An analysis of the relationship between public spending and private investments in Nigeria, Journal of Economics and Finance, 1(2), 78-91.

Nwosa, P. I., \& Ajibola, A. A. (2013). Is Exchange Rate in Nigeria Led by International Oil Price?, International Journal of Business and Economic Research (IJBER), 1(1), 175-182.

Nwosa, P. I. (2012) Domestic fuel price and the Nigerian macroeconomy, African Journal of Economic and Sustainable Development (AJESD), 1(4), 353-365.

Obida, G. W., \& Abu, N. (2010). Determinants of foreign direct investment in Nigeria: an empirical analysis, Global Journal of Human Social Sciences, 10(1), 26-34.

Ogunleye, E. K. (2008). Exchange rate volatility and foreign direct investment inflows in selected sub-sahara African countries (19702005)', PhD. Dissertation University of Ibadan. Retrieved on September 25, 2012 from http://www.csae.ox.ac.uk/conferences/2009-EDiA/papers/196-Ogunleye.pdf]

Okafor, H. O. (2012). Do domestic macroeconomic variables matter for foreign direct investment inflow in Nigeria?, Research Journal of Finance and Accounting, 3(9), 55-67.

Okpara, G. C., Ajuka, F. N., \& Nwaoha, W. C. (2012). An error correction model of the determinant of foreign direct investment: evidence from Nigeria, Munich Personal RePEc Archive (MPRA), Paper No. 36676.

Omisakin, O., Oyinlola, A., \& Adeniyi, O. (2010). Relative responsiveness of trade flows to changes in exchange rate and prices in selected ECOWAS countries: does Orcutt hypothesis hold?, Journal of Economics and International Finance, 2(6), 102-108.

Omojimite, B. U., \& Akpokodje, G. (2010). A comparative analysis of the effect of exchange rate volatility on exports in the CFA and NonCFA countries of Africa, Journal of Social Sciences, 24(1), 23-31.

Osinubi, T. S., \& Amaghionyeodiwe, L. A. (2009). Foreign direct investment and exchange rate volatility in Nigeria, International Journal of Applied Econometrics and Quantitative Studies, 6(2), 84-116.

Ozturk, I. (2006). Exchange rate volatility and trade: a literature survey, International Journal of Applied Econometrics and Quantitative Studies, 3(1), 85-102.

Ozturk, I., \& Kalyoncu, H. (2007). Foreign direct investment and growth: an empirical investigation based on cross-country comparison, Munich Personal RePEc Archive (MPRA), Paper No. 9636.

Petreski, M. (2009). Exchange-rate regime and economic growth: a review of the theoretical and empirical literature, Economics Discussion Paper No. 2009-31.

Prasad, E. S., Rajan, R. G., \& Subramanian, A. (2007). Foreign capital and economic growth, NBER Working Paper Series, No. 13619. 
Prati, A., Sahay, R., \& Tressel, T. (2003). Is there a case for sterilizing foreign aid?, macroeconomic challenges in low-income countries workshop (Washington: International Monetary Fund). Retrieved on May 15, 2013 from

http://www.imf.org/external/np/res/seminars/2003/lic/pdf/tt.pdf.

Rashid, A., \& Husain, F. (2010). Capital inflows, inflation and exchange rate volatility: an investigation for linear and nonlinear causal linkages, Pakistan Institute of Development Economics (PIDE) Islamabad, Working Papers, No. 63.

Schnabl, G. (2007). Exchange rate volatility and growth in small open economies at the EMU periphery, Working Paper Series, No. 773 I July. Available at http://ssrn.com/abstract_id $=955250$.

Shehu, A. A., \& Youtang, Z. (2012). Exchange rate volatility, trade flows and economic growth in a small open economy, International Review of Business Research Papers, 8(2), 118-131.

Shen, C. H., Lee, C. C., \& Lee, C. C. (2010). What makes international capital flows promote economic growth? an international crosscountry analysis', Scottish Journal of Political Economy, 57(5), 515-546.

Tang, S., Selvanathan, E. A., \& Selvanathan, S. (2008). Foreign direct investment, domestic investment, and economic growth in China: a time series analysis, United Nations University World Institute for Development Economics Research (UNU-WIDER) Research Paper, No. 2008/19.

Udoh, E., \& Egwaikhide, F. O. (2008). Exchange rate volatility, inflation uncertainty and foreign direct investment in Nigeria, Botswana Journal of Economics (BOJE), 5(7), 14-31.

Umoh, O. J., Jacob, A. O., \& Chuku A. C. (2012). Foreign direct investment and economic growth in Nigeria: an analysis of the endogenous effects, Current Research Journal of Economic Theory, 4(3), 53-66.

Waldkirch, A. (2008). The effects of foreign direct investment in Mexico since NAFTA, MPRA Paper No. 7975.

Walsh, J. P., \& Yu, J. (2010). Determinants of foreign direct investment: a sectoral and institutional approach, IMF Working Paper, Asia Pacific Department, WP/10/187. 